Плєхов В.А.

\title{
КЛІНІКО-АНАМНЕСТИЧНІ ХАРАКТЕРИСТИКИ АФЕКТИВНИХ ПОРУШЕНЬ У ХВОРИХ НА ШИЗОТИПОВИЙ РОЗЛАД
}

Запорізький державний медичний університет

\section{Plekhov V. \\ CLINICAL AND ANAMNESTIC CHARACTERISTICS OF AFFECTIVE DISORDERS IN PATIENTS WITH SCHIZOTYPIC DISORDER}

\section{Zaporizhzhia State Medical University}

\section{Резюме}

\begin{abstract}
3 метою виявлення клініко-анамнестичні характеристики афективних порушень у хворих на шизотиповий розлад протягом 2019-2020 рр. було досліджено 100 пацієнтів амбулаторно-поліклінічного відділення КНП «Обласний клінічний заклад з надання психіатричної допомоги» $3 О Р$ (м. Запоріжжя), у яких був встановлений діагноз «Шизотиповий розлад».
\end{abstract}

Матеріали і методи. Для вирішення поставленої мети були використані клініко-анамнестичний, клініко-психопатологічний, психодіагностичний та статистичний методи.

За результатами дослідження були встановлені анамнестичні кореляти шизотипового розладу в залежності від спектру афективних порушень: для хворих із переважанням депресивного афекту характерні дебют захворювання із дисоиіативної, псевдообсесивної депресивної та тривожної симптоматики, висока частота госпіталізацій до психіатричного стачіонару, підтримуюча терапія із застосуванням комбіначії антипсихотичних та антидепресивних препаратів, наявність вищої освіти, конфліктні відносини із близькими, перебування у шлюбі та наявність дітей; для хворих із ииклічною зміною афективних фаз характерні дебют захворювання із дисоціативної та депресивної симптоматики, висока частота госпіталізацій до психіатричного стачіонару, зловживання психоактивними речовинами, конфліктні відносини із близькими; для хворих зі станом афективного сплощення характерні стабільність перебігу захворювання із переважанням апато-абулічної та психопатоподібної симптоматики, зловживання психоактивних речовин, відносно низький рівень освіти, низькі показники працевлаштованості.

Висновки. Встановлено клініко-анамнестичні характеристики афективних порушень у хворих на шизотиповий розлад, серед них найбільше значення мають особливості ініціальної симптоматики, як підгрунтя для системи ранньої діагностики зазначених станів.

Ключові слова: шизотиповий розлад, шизофренія, афективні порушення, депресія, коморбідність y ncuxiampiï.

Вступ. Виявлення етіопатогенетичних механізмів формування психічної патології залишається одним із найбільш актуальних напрямків наукового пошуку в сучасному психіатричному дискурсі $[2,5]$.
Ретроспективний аналіз семіотичного наповнення наявної психічної патології дозволяє визначити ії вектор розвитку та закономірності перебігу, побудувати прогностичні моделі та сформувати підґрунтя 
для заходів ранньої діагностики. Особливо важливим і водночас складним є даний аналіз серед контингенту хворих на психічну патологію ендогенно-процесуального регістру, оскільки на перебіг даних захворювань впливає широкий спектр факторів: від особливостей мікросоціального оточення до наявності коморбідної психічної патології. у цьому контексті особливої уваги заслуговує шизотиповий розлад, або т.з. «малопрогредієнтна шизофренія» - артифіковано створена нозологічна група, клінічна семіотика якої представлена симптомами шизофренічного спектру, що за критеріями динаміки, структури та інтенсивності прояву не досягають рівня «великої» шизофренії та значно перевищують нозологічний ценз шизоїдного розладу особистості $[3,5,10]$.

Структурна неоднорідність шизотипового розладу, що викликана нечіткістю окреслення кола діагностичних критеріїв, і, як результат, значний поліморфізм представленої симптоматики, визначають значну актуальність дослідження особливостей формування та перебігу даної патології [4-6, 8].

Особливий науковий інтерес представляє аналіз анамнестичних характеристик шизотипового розладу, включно з висвітленням характеру т.з. «первинного надлому». Ряд дослідників стверджують, що саме спектр ініціальної симптоматики більшим чином визначає подальший перебіг захворювання [1, 7, 9-10].

Мета дослідження. На основі аналізу клініко-психопатологічного наповнення афективних порушень у хворих на шизотиповий розлад виявити їх клініко-анамнестичні характеристики.

Матеріали та методи. За умови надання інформованої згоди та 3 дотриманням принципів біоетики протягом 2019-2020 рр. було обстежено 128 хворих на шизотиповий розлад, що перебували на амбулаторному лікуванні у КНП «Обласний клінічний заклад з надання психіатричної допомоги» $30 P$ (м. Запоріжжя), серед яких для подальшого дослідження було відібрано 100 хворих. Підчас дослідження були використані наступні методи: клініко-анамнестичний, клініко-психопатологічний та психодіагностичний, що був реалізований шляхом використання Госпітальної шкали тривоги та депресії (Hospital Anxiety and Depression Scale, HADS), Оціночної шкали манії Янга (Young Mania Rating Scale, YMRS) та Шкали позитивних і негативних синдромів (Positive and Negative Syndrome Scale, PANSS). Статистична обробка отриманих даних була здійснена за допомогою програмного забезпечення «Excel» (Microsoft, CШA) та «STATISTICA» 13.0. («Statsoft», США) 3 використанням параметричних і непараметричних методів.

Результати дослідження. За результатами проведеного дослідження було виявлено поширеність афективних порушень різного спектру серед хворих на шизотиповий розлад на рівні 68\%. Серед цих хворих у 52 випадках спостерігалась уніполярна психопатологічна симптоматика депресивного спектру, її вираженість динамічно змінювалась у континуумі від повної відсутності до клінічно значимого рівня; цей контингент хворих увійшов до групи дослідження 1 (Г1). Групу дослідження 2 (Г2) було сформовано із 16 хворих, у яких була виявлена тенденція до циклічної зміни афективних фаз - депресивний афект змінювався фазами гіпоманікальних станів.

Інші 32 хворих демонстрували специфічні зміни афективної сфери, що шляхом співставлення даних психодіагностичного та клініко-психопатологічного досліджень були оцінені як афективне сплощення. Клінічне наповнення даного стану було представлено неспроможністю до вербального вираження власних емоцій, браком мімічної та пантомімічної експресій, що поєднувалось із вираженими гіпо- та парабулічними проявами. 3 даного контингенту хворих було сформовано групу дослідження 3 (ГЗ).

Сформований контингент був досліджений за рівнем представленості двох кластерів анамнестичних характеристик: перший кластер - пов'язаний із захворюванням, він включав в себе психопатологічне наповнення ініціальної симптоматики (т.з. «первинний надлом»), вік дебюту та тривалість захворювання, частоту поза- 
планових госпіталізацій до психіатричного стаціонару, тривалість та стійкість ремісії, характеристику загострень, досвід зловживання психоактивних речовин та ін.; другий кластер - набір анамнестичних характеристик, не пов'язаних із основним захворюванням, який включав у себе стать, обтяженість сімейного анамнезу психічними розладами, наявність супутньої соматичної патології, рівень отриманої освіти, соціально-побутові умови, працевлаштованість, подружній статус, наявність дітей та ін.

В табл. 1 наведено порівняння частоти представленості ініціальної психопатологічної симптоматики різного спектру серед контингенту груп дослідження.

Таблиця 1

Компаративний аналіз поширеності ініціальної психопатологічної симптоматики різного спектру серед Г1, Г2 та Гз

\begin{tabular}{|c|c|c|c|c|c|c|c|c|c|}
\hline \multirow{3}{*}{$\begin{array}{c}\text { Спектр ініціальної } \\
\text { симптоматики }\end{array}$} & \multicolumn{6}{|c|}{ Поширеність } & \multicolumn{3}{|c|}{$p\left(\chi^{2}\right)$ в парах груп } \\
\hline & \multicolumn{2}{|c|}{$\Gamma 1(n=52)$} & \multicolumn{2}{|c|}{ Г2 (n=16) } & \multicolumn{2}{|c|}{ Г3 (n=32) } & \multicolumn{2}{|c|}{ Г1 } & \multirow{2}{*}{$\begin{array}{l}\text { 「2 } \\
\text { 「3 }\end{array}$} \\
\hline & $\begin{array}{l}\text { Абс., } \\
\text { осіб }\end{array}$ & Відн., \% & $\begin{array}{l}\text { Абс., } \\
\text { осіб }\end{array}$ & Відн., \% & $\begin{array}{l}\text { Абс., } \\
\text { осіб }\end{array}$ & Відн., \% & Г2 & $\lceil 3$ & \\
\hline Параноїдний & 10 & 19,2 & 4 & 25,0 & 4 & 12,5 & 0,62 & 0,42 & 0,27 \\
\hline Апато-абулічний & 3 & 5,8 & 1 & 6,2 & 16 & 50,0 & 0,95 & $<0,001^{*}$ & 0,003 \\
\hline $\begin{array}{l}\text { Сенесто-іпохон- } \\
\text { дричний }\end{array}$ & 4 & 7,7 & 1 & 6,2 & 1 & 3,1 & 0,85 & 0,39 & 0,61 \\
\hline Дисоціативний & 11 & 21,2 & 3 & 18,7 & 0 & 0 & 0,84 & 0,005 & 0,01 \\
\hline Астенічний & 4 & 7,7 & 1 & 6,2 & 0 & 0 & 0,85 & 0,11 & 0,15 \\
\hline Псевдообсесивний & 7 & 13,5 & 0 & 0 & 0 & 0 & 0,13 & 0,03 & 1 \\
\hline Депресивний & 6 & 11,5 & 3 & 18,7 & 0 & 0 & 0,46 & 0,04 & 0,01 \\
\hline Тривожний & 6 & 11,5 & 1 & 6,2 & 0 & 0 & 0,55 & 0,04 & 0,15 \\
\hline Маніакальний & 0 & 0 & 1 & 6,2 & 0 & 0 & 0,07 & 1 & 0,15 \\
\hline Психопатоподібний & 1 & 1,9 & 1 & 6,2 & 11 & 34,4 & 0,38 & $<0,001$ & 0,03 \\
\hline
\end{tabular}

Примітки: * - статистично значимі відмінності на рівні $p<0,05$ виділені сірою заливкою.

За результатами проведеного порівняльного аналізу не було виявлено статистично значимих відмінностей між групами дослідження за ознакою поширеності параноїдної симптоматики на ініціальному етапі захворювання: вона була виявлена у 10 хворих (19,2\%) Г1, 4 хворих (25\%) Г2 та 4 хворих (12,5\%) Г3. Даний спектр симптомів найчастіше клінічно був представлений вторинними маячними ідеями переслідування, впливу та відношення.

Початок захворювання із розвитком апато-абулічної симптоматики був більш характерний для хворих ГЗ, тут її поширеність досягала 50\% (16 хворих), що статис- тично достовірно більше порівняно із Г1, де даний показник сягав 5,8\% (3 хворих), та Г2, де даний показник був на рівні 6,2\% (1 хворий).

Поширеність сенесто-іпохондричної симптоматики на ініціальному етапі захворювання не мала статистично значимих відмінностей поміж груп дослідження: вона була виявлена у 4 хворих (7,7\%) Г1, 1 хворого $(6,2 \%)$ Г2 та 1 хворого $(3,1 \%)$ г3.

Дисоціативна симптоматика на початкових етапах захворювання мала місце лише серед хворих Г1 та Г2, її поширеність досягала 21,2\% (11 хворих) та 18,7\% (3 хворих) відповідно. 
Астенічний симптомокомплекс був розцінений як ініціальний у 4 хворих $(7,7 \%)$ $\lceil 1,1$ хворого $(6,2 \%)$ Г2 та не мав представленості серед контингенту ГЗ.

Ініціальна симптоматика псевдообсесивного спектру була характерна лише для Г1: 7 хворих (13,5\%) цієї групи мали ознаки обсесій, ідеаторних автоматизмів та стереотипій, що жодним чином не були пов'язані із можливими психотравмуючими факторами або не відображали їх контекст.

Превалювання депресивного афекту в рамках ініціального комплексу симптомів було виявлено у 6 хворих $(11,5 \%)$ Г1 та 3 хворих (18,7\%) Г2, що статистично більше ( $p=0,04$ та 0,01 відповідно) порівняно із Гз.

Статистично значимі розбіжності також були виявлені за показником поширеності ініціальної симптоматики тривожного спектру між Г1, де цей показник сягав 11,5\%
(6 хворих), та ГЗ, де таких випадків не було зафіксовано. Початок захворювання із анксіозної симптоматики мав місце лише у 1 хворого $(6,2 \%)\lceil 2$.

Маніоформна симптоматика мала місце на початку захворювання лише у 1 хворого $(6,2 \%)$ із Г2 та не була виявлена у жодного із хворих Г1 таГз.

Психопатоподібна симптоматика в рамках ініціального психопатологічного комплексу була виявлена у 11 хворих (34,4\%) Г3, що статистично достовірно більше порівняно із Г1 та Г2, де даний показник був представлений лише у 1 хворого з кожної групи (1,9\% та 6,2\% відповідно).

В табл. 2 наведено порівняння частоти представленості персистуючої психопатологічної симптоматики різного спектру, що призводила до позапланових госпіталізацій контингенту груп дослідження.

Таблиця 2

Компаративний аналіз поширеності персистуючої психопатологічної симптоматики різного спектру серед Г1, Г2 та ГЗ

\begin{tabular}{|c|c|c|c|c|c|c|c|c|c|}
\hline \multirow{3}{*}{$\begin{array}{l}\text { Спектр персистуючої } \\
\text { симптоматики }\end{array}$} & \multicolumn{6}{|c|}{ Поширеність } & \multicolumn{3}{|c|}{$p\left(\chi^{2}\right)$ в парах груп } \\
\hline & \multicolumn{2}{|c|}{$\Gamma 1(n=52)$} & \multicolumn{2}{|c|}{ Г2 (n=16) } & \multicolumn{2}{|c|}{$\Gamma 3$ (n=32) } & \multicolumn{2}{|l|}{$\lceil 1$} & \multirow{2}{*}{$\begin{array}{l}\Gamma 2 \\
33\end{array}$} \\
\hline & $\begin{array}{l}\text { Абс., } \\
\text { осіб }\end{array}$ & $\begin{array}{l}\text { Відн., } \\
\%\end{array}$ & $\begin{array}{l}\text { Абс., } \\
\text { осіб }\end{array}$ & $\begin{array}{l}\text { Вiдн., } \\
\%\end{array}$ & $\begin{array}{l}\text { Aбc., } \\
\text { ocí }\end{array}$ & $\begin{array}{l}\text { Відн., } \\
\%\end{array}$ & Г2 & $\lceil 3$ & \\
\hline Параноїдний & 0 & 0 & 2 & 6,2 & 0 & 0 & $<0,001^{*}$ & 1 & 0,04 \\
\hline Апато-абулічний & 2 & 3,8 & 0 & 0 & 18 & 56,2 & 0,43 & $<0,001$ & $<0,001$ \\
\hline Сенесто-іпохондричний & 3 & 5,8 & 0 & 0 & 0 & 0 & 0,33 & 0,17 & 1 \\
\hline Дисоціативний & 0 & 0 & 0 & 0 & 0 & 0 & 1 & 1 & 1 \\
\hline Астенічний & 4 & 7,7 & 1 & 6,2 & 3 & 9,4 & 0,85 & 0,79 & 0,71 \\
\hline Псевдообсесивний & 6 & 11,5 & 1 & 6,2 & 0 & 0 & 0,54 & 0,04 & 0,15 \\
\hline Депресивний & 4 & 7,7 & 1 & 6,2 & 1 & 3,1 & 0,85 & 0,39 & 0,61 \\
\hline Тривожний & 29 & 55,8 & 5 & 37,5 & 1 & 3,1 & 0,08 & $<0,001$ & 0,005 \\
\hline Маніакальний & 0 & 0 & 4 & 25,0 & 0 & 0 & $<0,001$ & 1 & 0,003 \\
\hline Психопатоподібний & 4 & 7,7 & 2 & 12,5 & 9 & 28,1 & 0,55 & 0,01 & 0,22 \\
\hline
\end{tabular}

Примітки: * - статистично значимі відмінності на рівні $\mathrm{p}<0,05$ виділені сірою заливкою.

Клінічна картина захворювання із переважанням параноїдної симптоматики під час загострення його перебігу була характерна лише для Г2 - 2 хворих (6,2\%) мали досвід позапланових госпіталізацій до психіатричного стаціонару через актуалізацію персекуторних ідей. Даний спектр симптомів не був виявлений у хворих Г1 та ГЗ. 
Посилення апато-абулічних проявів ставали причиною госпіталізацій 18 хворих $(56,2 \%)$ Г3, що статистично більше, ніж Г1, де таких випадків було зафіксовано 2 (3,8\%), та $\ulcorner 2$, де даний спектр симптомів не був зафіксований.

За показником поширеності сенесто-іпохондричної симптоматики, під час загострення захворювання статистично значимих розбіжностей між групами дослідження не було виявлено. Даний спектр симптомів був виявлений лише у 3 хворих (5,8\%) Г1.

Дисоціативна симптоматика не була виявлена серед контингенту груп дослідження в період загострення перебігу захворювання.

Превалювання астенічного симптомокомплексу під час загострення захворювання мало місце у 4 хворих $(7,7 \%) \Gamma 1,1$ хворого $(6,2 \%)$ Г2 та 3 хворих $(9,4 \%)$ ГЗ. Різниця між групами дослідження за цим показником $\epsilon$ статистично не значимими.

Статистично значимі розбіжності були виявлені за показником поширеності персистуючої симптоматики псевдообсесивного спектру між Г1, де дані прояви демонстрували 6 хворих (11,5\%), та Г3, де таких випадків не було зафіксовано. Загострення захворювання із переважанням псевдообсесивних симптомів було виявлено у 1 хворого $(6,2 \%)$ Г2.

Ізольована депресивна симптоматика ставала причиною для госпіталізацій 4 хворих (7,7\%) Г1, 1 хворого (6,2\%) Г2 та 1 хворого $(3,1 \%)$ Гз. Різниця між групами дослі- дження за цим показником є статистично не значимими.

Семіотичне наповнення клінічної картини захворювання в період його загострення у 29 хворих (55,8\%) Г1 та 5 хворих $(37,5 \%)$ Г2 було представлено тривожною симптоматикою, що достовірно більше, порівняно із ГЗ, де даний показник сягав рівня 3,1\% (1 хворий). Слід відмітити, що, не зважаючи на превалювання анксіозного компоненту у клінічній картині захворювання, він не був представлений ізольовано та завжди супроводжувався депресивним та/або параноїдним компонентами.

Загострення захворювання із превалюванням симптоматики маніакального спектру було типовим лише для хворих Г2 - 4 хворих (25\%) цієї групи були госпіталізовані до психіатричного стаціонару в такому стані.

Психопатоподібна симптоматика частіше ставала причиною госпіталізацій хворих Г3, таких випадків було зафіксовано 9 $(28,1 \%)$, що значно менше, ніж у Г1 (4 хворих) та Г2 (2 хворих).

Порівняння семіотичного наповнення клінічної картини в групах дослідження на ініціальному етапі та у віддаленому періоді захворювання дає змогу визначити закономірності синдромокінезу психопатологічної симптоматики в залежності від спектру афективної патології.

В табл. 3 представлено порівняння частоти представленості інших анамнестичних факторів, пов'язаних із захворюванням, серед контингенту груп дослідження.

Таблиця 3

Компаративний аналіз поширеності анамнестичних факторів, пов'язаних із захворюванням, серед Г1, Г2 та ГЗ

\begin{tabular}{|c|c|c|c|c|c|c|c|c|c|}
\hline \multirow{3}{*}{ Фактори } & \multicolumn{6}{|c|}{ Поширеність } & \multicolumn{3}{|c|}{$p\left[\chi^{2}\right]$ в парах груп } \\
\hline & \multicolumn{2}{|c|}{$\Gamma 1(n=52)$} & \multicolumn{2}{|c|}{ Г2 (n=16) } & \multicolumn{2}{|c|}{ 「3 (n=32) } & \multicolumn{2}{|c|}{$\lceil 1$} & \multirow{2}{*}{$\begin{array}{l}\Gamma 2 \\
\Gamma 3\end{array}$} \\
\hline & $\begin{array}{l}\text { Абс., } \\
\text { осіб }\end{array}$ & $\underset{\%}{\text { Відн., }}$ & $\begin{array}{l}\text { Абс., } \\
\text { осіб }\end{array}$ & $\underset{\%}{\text { Відн., }}$ & $\begin{array}{l}\text { Абс., } \\
\text { осіб }\end{array}$ & $\underset{\%}{\text { Відн., }}$ & Г2 & $\lceil 3$ & \\
\hline Ранній дебют (до 18 років) & 12 & 23,1 & 5 & 31,2 & 8 & 25,0 & 0,51 & 0,84 & 0,65 \\
\hline Дебют у віці 18-25 років & 19 & 36,5 & 6 & 37,5 & 16 & 50,0 & 0,94 & 0,22 & 0,41 \\
\hline Дебют у віці 26-35 років & 15 & 28,8 & 5 & 31,2 & 6 & 18,7 & 0,85 & 0,3 & 0,33 \\
\hline
\end{tabular}




\begin{tabular}{|c|c|c|c|c|c|c|c|c|c|}
\hline \multirow{4}{*}{ Фактори } & & & & & & & \multicolumn{3}{|c|}{ Продовження таблиці } \\
\hline & \multicolumn{6}{|c|}{ Поширеність } & \multicolumn{3}{|c|}{$\mathrm{p}\left(\chi^{2}\right)$ в парах груп } \\
\hline & \multicolumn{2}{|c|}{$\Gamma 1(n=52)$} & \multicolumn{2}{|c|}{ Г2 (n=16) } & \multicolumn{2}{|c|}{ Г3 (n=32) } & \multicolumn{2}{|c|}{$\lceil 1$} & \multirow{2}{*}{$\begin{array}{l}\text { Г2 } \\
\text { Г3 }\end{array}$} \\
\hline & $\begin{array}{l}\text { Абc., } \\
\text { осіб }\end{array}$ & Відн., & $\begin{array}{l}\text { Абс., } \\
\text { осіб }\end{array}$ & $\begin{array}{l}\text { Biдн., } \\
\%\end{array}$ & $\begin{array}{l}\text { Абс., } \\
\text { осіб }\end{array}$ & $\begin{array}{l}\text { Відн., } \\
\%\end{array}$ & Г2 & $\lceil 3$ & \\
\hline $\begin{array}{l}\text { Пізній дебют } \\
\text { (більше } 35 \text { років) }\end{array}$ & 6 & 11,5 & 0 & 0 & 2 & 6,2 & 0,15 & 0,42 & 0,31 \\
\hline $\begin{array}{l}\text { Тривалість захворювання } \\
\text { до } 5 \text { років }\end{array}$ & 6 & 11,5 & 2 & 12,5 & 2 & 6,2 & 0,92 & 0,42 & 0,46 \\
\hline $\begin{array}{l}\text { Тривалість захворювання } \\
\text { 5-10 років }\end{array}$ & 9 & 17,3 & 3 & 18,7 & 8 & 25,0 & 0,89 & 0,39 & 0,68 \\
\hline $\begin{array}{l}\text { Тривалість захворювання } \\
\text { більше } 10 \text { років }\end{array}$ & 37 & 71,2 & 11 & 68,7 & 22 & 68,7 & 0,85 & 0,81 & 0,15 \\
\hline $\begin{array}{l}\text { Більше } 1 \text { госпіталізацій до } \\
\text { психіатричного стаціонару } \\
\text { протягом минулого року }\end{array}$ & 19 & 36,5 & 7 & 43,7 & 5 & 15,6 & 0,6 & $0,04^{*}$ & 0,03 \\
\hline Інвалідність || гр. & 10 & 19,2 & 2 & 12,5 & 10 & 31,2 & 0,53 & 0,21 & 0,16 \\
\hline Інвалідність ||| гр. & 21 & 40,4 & 7 & 43,7 & 12 & 37,5 & 0,81 & 0,79 & 0,67 \\
\hline $\begin{array}{l}\text { Безмедикаментозна } \\
\text { ремісія }\end{array}$ & 1 & 1,9 & 1 & 6,2 & 0 & 0 & 0,37 & 0,43 & 0,15 \\
\hline Пт ${ }^{\star *}$ антидепресантом & 4 & 7,7 & 0 & 0 & 0 & 0 & 0,25 & 0,11 & 1 \\
\hline ПТ нейролептиком & 18 & 34,6 & 8 & 50,0 & 16 & 50,0 & 0,27 & 0,16 & 1 \\
\hline $\begin{array}{l}\text { ПТ комбінацією декількох } \\
\text { нейролептиків }\end{array}$ & 15 & 28,8 & 7 & 43,7 & 13 & 40,6 & 0,27 & 0,26 & 0,83 \\
\hline $\begin{array}{l}\text { ПТ комбінацією нейролеп- } \\
\text { тиків та антидепресантів }\end{array}$ & 12 & 23,1 & 0 & 0 & 2 & 6,2 & 0,03 & 0,04 & 0,43 \\
\hline $\begin{array}{l}\text { ПТ комбінацією нейролеп- } \\
\text { тиків та нормотиміків }\end{array}$ & 2 & 3,8 & 0 & 0 & 1 & 3,1 & 0,43 & 0,86 & 0,47 \\
\hline $\begin{array}{l}\text { Зловживання одним або } \\
\text { декількома ПАР }\end{array}$ & 5 & 9,6 & 6 & 37,5 & 9 & 28,1 & 0,001 & 0,03 & 0,51 \\
\hline
\end{tabular}

Примітки: * статистично значимі відмінності на рівні $\mathrm{p}<0,05$ виділені сірою заливкою; ** ПТ - підтримуюча терапія; ***ПАР - психоактивна речовина.

Т.3. «первинний надлом» у абсолютної більшості хворих Г1, Г2 та ГЗ відбувся у віці від 18 до 25 років. Слід відзначити, що у значної кількості хворих дебют захворювання припадав на більш пізній період: 40,4\% хворих Г1, 31,2\% хворих Г2 та 25\% хворих ГЗ потрапили у поле зору психіатрів у віці старше 26 років. Цей феномен обумовлений малою прогредієнтністю перебігу захворювання: інтенсивність психопатологічних проявів не досягала значимого рівня протягом тривалого часу, залишаючись нижче клінічного цензу досліджуваної нозології.
За показником тривалості захворювання також не було виявлено жодних розбіжностей з-поміж груп дослідження: у більшості хворих цей показник перевищує 10 років.

Для хворих Г1 та Г2 були більш характерні часті госпіталізації до психіатричного стаціонару порівняно із Гз: більше 1 позапланової госпіталізації протягом останнього року мали лише 5 хворих ГЗ проти 19 хворих Г1 та 7 хворих Г2.

За критерієм наявності інвалідності у зв'язку із психічним захворюванням, а також за її структурою жодних розбіжностей між 
групами дослідження не було виявлено. Середній показник стійкої втрати працездатності серед усього контингенту дослідження склав $62 \%$.

Також було проаналізовано схеми психофармакотерапії сформованих груп дослідження. У якості підтримуючої терапії найчастіше використовувалась монотерапія препаратами із групи атипових нейролептиків (34,6\% у Г1, 50\% у Г2 та Г3), комбінація декількох антипсихотичних препаратів (28,8\% у Г1, 43,7\% у Г2 та 40,6\% у Г3) та поєднання нейролептику із антидепресантом. Остання схема терапії значно частіше використовувалась у Г1 - 23,1\% хворих, у той час коли у Г2 вона не застосовувалась взагалі, а у ГЗ - лише у 2 хворих (6,2\%).

Було виявлено закономірності між досвідом зловживання психоактивних речовин та афективним статусом хворих груп дослідження: серед хворих Г1 така частка осіб достовірно менша $(9,6 \%)$ порівняно із Г2 (37,5\%) та Г3 (28,1\%). Найбільш поширеними були факти вживання канабіноїдів (12 хворих), алкоголю (6 хворих), синтетичних катінонів (4 хворих) та їх комбінації.

В табл. 4 представлено порівняння частоти представленості інших анамнестичних факторів серед контингенту груп дослідження, що не пов'язані із захворюванням.

Табличя 4

Компаративний аналіз поширеності анамнестичних факторів, не пов'язаних із захворюванням, серед Г1, Г2 та Гз

\begin{tabular}{|c|c|c|c|c|c|c|c|c|c|}
\hline \multirow{3}{*}{ Фактори } & \multicolumn{6}{|c|}{ Поширеність } & \multicolumn{3}{|c|}{$\mathrm{p}\left(\chi^{2}\right)$ в парах груп } \\
\hline & \multicolumn{2}{|c|}{$\Gamma 1(n=52)$} & \multicolumn{2}{|c|}{ Г2 (n=16) } & \multicolumn{2}{|c|}{ 「3 (n=32) } & \multicolumn{2}{|c|}{$\Gamma 1$} & \multirow{2}{*}{$\begin{array}{c}\text { Г2 } \\
\text { Г3 }\end{array}$} \\
\hline & $\begin{array}{l}\text { Абс., } \\
\text { осіб }\end{array}$ & Відн., & $\begin{array}{l}\text { Абс., } \\
\text { осіб }\end{array}$ & $\begin{array}{l}\text { Відн., } \\
\%\end{array}$ & $\begin{array}{l}\text { Абс. } \\
\text { осіб }\end{array}$ & $\begin{array}{l}\text { Відн., } \\
\%\end{array}$ & Г2 & $\lceil 3$ & \\
\hline Чоловіча стать & 33 & 63,5 & 6 & 37,5 & 26 & 81,2 & \multirow{2}{*}{0,07} & \multirow{2}{*}{0,08} & \multirow{2}{*}{$0,02^{*}$} \\
\hline Жіноча стать & 19 & 36,5 & 10 & 62,5 & 6 & 18,8 & & & \\
\hline $\begin{array}{l}\text { Обтяженість сімейного } \\
\text { анамнезу психічними } \\
\text { захворюваннями }\end{array}$ & 15 & 28,8 & 7 & 43,7 & 12 & 37,5 & 0,27 & 0,41 & 0,68 \\
\hline $\begin{array}{l}\text { Супутня соматична пато- } \\
\text { логія }\end{array}$ & 24 & 46,2 & 6 & 37,5 & 14 & 43,7 & 0,54 & 0,83 & 0,68 \\
\hline Середня освіта & 13 & 25,0 & 4 & 25,0 & 14 & 43,7 & 1 & 0,07 & 0,21 \\
\hline Середня спеціальна освіта & 17 & 32,7 & 7 & 43,7 & 12 & 37,5 & 0,42 & 0,65 & 0,68 \\
\hline Вища освіта & 22 & 42,3 & 5 & 31,2 & 6 & 18,8 & 0,43 & 0,02 & 0,33 \\
\hline $\begin{array}{l}\text { Скрутне матеріальне ста- } \\
\text { новище }\end{array}$ & 10 & 19,2 & 5 & 31,2 & 12 & 37,5 & 0,31 & 0,06 & 0,67 \\
\hline $\begin{array}{l}\text { Несприятливі умови про- } \\
\text { живання }\end{array}$ & 7 & 13,5 & 3 & 18,7 & 9 & 28,1 & 0,6 & 0,09 & 0,48 \\
\hline $\begin{array}{l}\text { Конфліктні відносини із } \\
\text { близькими }\end{array}$ & 26 & 50,0 & 10 & 62,5 & 10 & 31,2 & 0,38 & 0,09 & 0,04 \\
\hline Перебування у шлюбі & 11 & 21,2 & 0 & 0 & 1 & 3,1 & 0,04 & 0,02 & 0,47 \\
\hline Наявність дітей & 12 & 23,1 & 1 & 6,2 & 2 & 6,2 & 0,13 & 0,04 & 1 \\
\hline Працевлаштованість & 15 & 28,8 & 6 & 37,5 & 4 & 12,5 & 0,51 & 0,08 & 0,04 \\
\hline
\end{tabular}

Примітки: * - статистично значимі відмінності на рівні $p<0,05$ виділені сірою заливкою. 
Не зважаючи на те, що за критерієм статі, статистично значимі відмінності були виявлені лише між Г3 та Г2, чоловічу стать можливо достовірно $(p=0,02)$ розглядати як фактор виникнення афективної патології (незалежно від їі спектру) серед хворих на шизотиповий розлад.

За критерієм наявності обтяженості сімейного анамнезу психічними захворюваннями жодних статистично значимих відмінностей між групами дослідження не було виявлено. Найбільш поширеними психічними порушеннями у близьких родичів досліджуваних хворих були ендогенно-процесуальні розлади, афективна патологія та алкоголізм.

За критерієм наявності супутньої соматичної патології жодних розбіжностей між групами дослідження також не було виявлено.

Виявлено закономірності між рівнем освіти та особливостями афективної сфери хворих: для Г1 був характерний більш високий рівень освіти (частко осіб, що закінчили вищі навчальні заклади складала 42,3\%); у Г2 - превалювали хворі із середньо-спеціальною освітою (43,7\%); у Г3 - найбільш поширеною була середня освіта (43,7\%).

Конфліктні відносини із близьким були більш характерні для Г1, де про їх наявність повідомило 26 (50\%) хворих, та Г2, де вони були виявлені у 10 (62,5\%) хворих: саме нестабільний афективний фон хворих ставав причиною для сімейних сварок. За іншими маркерами соціально-побутових умов (скрутне матеріальне становище та несприятливі умови проживання) статистично значимих відмінностей між групами дослідження не було виявлено.

Значимі відмінності також були виявлені у сімейному статусі груп дослідження. Частка хворих Г1, що перебували у шлюбі, сягала $21,2 \%$, що значно більше, аніж у Г2, де таких випадків не було виявлено, та ГЗ, де лише 1 $(3,1 \%)$ хворий був одружений. Комбінація відносно великої частки хворих, що перебувають у шлюбі, із високою частотою конфліктних відносин із близьким у Г1 опосередковано свідчить про збереження критичного відношення до свого захворювання.
Аналогічні відмінності були виявлені між групами дослідження і за показником наявності дітей. Частка хворих Г1, які мали дітей, сягала 23,1\%, що значно більше, аніж у Г3, де про наявність дітей повідомило 2 $(6,2 \%)$ хворих. Лише у 1 (6,2\%) хворого Г2 були діти.

За показником працевлаштованості відмінності були виявлені лише між Г2, де частка хворих, що мали роботу, сягала $37,5 \%$ та ГЗ, де працювало лише 4 (12,5\%) хворих. У Г1 роботу мали $15(28,8 \%)$ хворих.

\section{Висновки}

1. Встановлено клініко-анамнестичні характеристики афективних порушень у хворих на шизотиповий розлад.

2. Для хворих на шизотиповий розлад із переважанням депресивного афекту характерні: дебют захворювання із дисоціативної, псевдообсесивної депресивної та тривожної симптоматики; загострення захворювання із превалюванням псевдообсесивної та тривожної симптоматики; висока частота госпіталізацій до психіатричного стаціонару, підтримуюча терапія із застосуванням комбінації антипсихотичних та антидепресивних препаратів; наявність вищої освіти; конфліктні відносини із близькими, перебування у шлюбі та наявність дітей.

3. Для хворих на шизотиповий розлад із циклічною зміною афективних фаз характерні: дебют захворювання із дисоціативної та депресивної симптоматики; загострення захворювання із превалюванням тривожної та маніакальної симптоматики; висока частота госпіталізацій до психіатричного стаціонару; зловживання психоактивних речовин; конфліктні відносини із близькими.

4. Для хворих на шизотиповий розлад із станом афективного сплощення характерні: стабільність клінічної симптоматики протягом перебігу захворювання із переважанням апато-абулічної та психопатоподібної симптоматики; зловживання психоактивними речовинами; відносно низький рівень освіти; низькі показники працевлаштованості. 


\section{СПИСОК ЛІТЕРАТУРИ:}

1. Барденштейн Л. М., Краховецкая Д. С., Щербакова И. В., Крупкин А. Г. Сравнительная оценка эффективности лечения сезонных депрессий у больных шизотипическим расстройством. Тюменский медицинский журнал. 2012. № 1. С. 6-7.

2. Гриневич Є.Г., Мішиєв В.Д., Кушнір А.М. та ін. Алгоритм встановлення функціонального діагнозу хворим на шизофренію, шизотипові та маячні розлади : Методичні рекомендації. - К.: НМАПО імені П.Л. Шупіка, 2012. - 38 с.

3. Кобзова М. П. Динамика когнитивных функций и социальная адаптация у пациентов с шизотипическим расстройством (ШТР). Медицинская психология в России. 2015. № 1 (30). С. 9.

4. Потапова В. А. Полимодальная психотерапия, интеграция методов в лечении шизотипического расстройства. Тюменский медицинский журнал. 2012. № 1. С. 47.

5. Смулевич А.Б. Малопрогредиентная шизофрения и пограничные состояния. М.: Чеховский печатный двор, 2017. 304 с.

6. Смулевич А. Б., Дубницкая Э. Б., Читлова В. В. Расстройства личности и депрессия. Журнал неврологии и психиатрии им. С.С.Корсакова. 2012. № 9. С. 4-11.

7. Степанов И. Л., Ваксман А. В. Особенности течения циркулярных депрессий у больных с сопутствующим личностным расстройством. Социальная и клиническая психиатрия. 2013. Т. 23, № 4. С. $32-36$.

8. Martin E.A., Cicero D.C., Kerns J.G. Social anhedonia, but not positive schizotypy, is associated with poor affective control. Personal Disord. 2012. № 3. P. 263-272.

9. Premkumar P., Ettinger U., Inchley-Mort S. et al. Neural processing of social rejection: the role of schizotypal personality traits. Hum. Brain Mapp. 2012. № 33. P. 695-706.

10. Raynal P. Goutaudier N. Nidetch V. et al. Typology of schizotypy in non-clinical young adults: Psychopathological and personality disorder traits correlates. Psychiatry Res. 2016. № 30 (246). P. 182-187.

\section{PEЗЮME \\ КЛИНИКО-АНАМНЕСТИЧЕСКИЕ ХАРАКТЕРИСТИКИ АФФЕКТИВНЫХ НАРУШЕНИЙ У БОЛЬНЫХ ШИЗОТИПИЧЕСКИМ РАССТРОЙСТВОМ}

\author{
Плехов В.А. \\ Запорожский государственный медицинский \\ университет
}

С целью выявления клинико-анамнестических характеристик афрективных нарушений у больных шизотипическим расстройством в течение 2019-2020 г2. было обследовано 100 пациентов амбулаторно-поликлинического отделения КНУ «Областное клиническое учреждение оказания психиатрической помощи» $30 \mathrm{C}$ (г. Запорожье), которым был установлен диагноз «Шизотипическое расстройство».

Материалы и методы. Для решения поставленной цели были использованы клинико-анамнестический, клинико-психопатологический, психодиагностический $и$ статистический методы.

В результате исследования были установлены анамнестические корреляты шизотипического расстройства в зависимости от спектра аффективных нарушений: для боль- ныхспреобладанием депрессивного аффекта характерны дебют заболевания с диссочиативной, псевдообсессивной, депрессивной и тревожной симптоматики, высокая частота госпитализаций в психиатрический стационар, поддерживающая терапия с применением комбинации антипсихотических и антидепрессивных препаратов, наличие высшего образования, конфрликтные отношения с близкими, пребывания в браке и наличие детей. Для больных с циклической сменой афрективных фаз характерны дебют заболевания с диссочиативной и депрессивной симптоматикой, высокая частота госпитализаций в психиатрический стационар, злоупотребление психоактивными веществами, конфликтные отношения с близкими. Для больных в состоянии аффрективного уплощения характерны стабильность течения заболевания с преобладанием апатоабулической и психопатоподобной симптоматики, злоупотребление психоактивными веществами, относительно низкий уровень образования, низкие показатели занятости.

Выводы. Выявлены клинико-анамнестические характеристики аффективных нарушений у больных шизотипическим расстройством, среди них наибольшее значение имеют особенности инициальной симпто- 
матики, как основа для системы ранней диагностики указанных состояний.

Ключевые слова: шизотипическое расстройство, шизофрения, аффективные нарушения, депрессия, коморбидность в психиampuu.

\section{SUMMARY \\ CLINICAL AND ANAMNESTIC CHARACTERISTICS OF AFFECTIVE DISORDERS IN PATIENTS WITH SCHIZOTYPIC DISORDER}

\author{
Plekhov V. \\ Zaporizhzhia State Medical University
}

The goal. In order to identify the clinical-anamnestic characteristics of affective disturbances in patients with schizotypic disorder during 20192020100 patients of the outpatient department of the "Regional Clinical Institution for the Provision of Psychiatric Care» (Zaporizhzhia) with «Schizotypic Disorder» diagnose were examined. Materials and methods. To solve this goal, clinical-anamnestic, clinical-psychopathological, psychodiagnostical and statistical methods were used.

As a result of the study, anamnestic correlates of schizotypic disorder depending on the spectrum of affective disturbances were established: patients with a predominance of depressive affect are characterized by presents of dissociative, pseudo-obsessive, depressive and anxiety symptoms at the beginning stage of the disease, a high frequency of hospitalizations in a psychiatric hospital, a combination of antipsychotic and antidepressant drugs as a supportive therapy, higher education, conflict relationships with relatives, being married and having children; patients with a cyclical change of affective phases are characterized by presents of dissociative and depressive symptoms at the beginning stage of disease, a high frequency of hospitalizations in a psychiatric hospital, misuse of psychoactive substances, conflict relationships relatives; patients in a state of affective flattening are characterized by the stability of the course of the disease with a predominance of apathy-abulic and psychopathic symptoms, misuse of psychoactive substances, a relatively low level of education, low employment rates.

Conclusions. Clinical and anamnestic characteristics of affective disorders in patients with schizotypic disorder were revealed, among them the features of the initial symptomatology are of the greatest importance, as the basis for the system of early diagnosis of these conditions.

Keywords: schizotypic disorder, schizophrenia, affective disorders, depression, comorbidity in psychiatry.

\section{АВТОРСЬКА ДОВІДКА}

- Плєхов Владислав Андрійович - аспірант кафедри психіатрії, психотерапії, загальної та медичної психології, наркології та сексології, Запорізький державний медичний університет

- Адреса: проспект Маяковського, 26, м. 3апоріжжя, Україна, 69035

- Тел.: (061) 233-96-66

- E-mail:mr.zetto12@gmail.com
- Плехов Владислав Андреевич - аспирант кафедры психиатрии, психотерапии, общей и медицинской психологии, наркологии и сексологии, Запорожский государственный медицинский университет

- Адрес: проспект Маяковского, 26, г. Запорожье, Украина, 69035

- Тел.: (061) 233-96-66

- E-mail:mr.zett012@gmail.com
- Pliekhov Vladyslav - PhD student of Departments of Psychiatry, Psychotherapy, General and Medical Psychology, Narcology and Sexology, Zaporizhzhia State Medical University

- Address: Mayakovsky Avenue, 26, Zaporizhzhia, Ukraine, 69035

- Tel.: (061) 233-96-66

- E-mail:mr.zett012@gmail.com

Стаття надійшла до редакції 03.11.2021 p. у разі виникнення питань до автора статmi, звертайтесь до редакції журналу info@ujmh.net 